\title{
DOEIPO/91289- TI
}

Technical Report

$\mathrm{DOE} / \mathrm{PC} / 91289--\mathrm{Tl}$

DE92 007942

September 1, 1991 through November 30, 1991

Contract No.:

DE EG-22-91PC-91289

Project Title:

Characterization of the Organic-Sulfur-Degrading Enzymes

Principal Investigator: Nancy W.Y. Ho

LORRE

Purdue University

1295 Potter Building

West Lafayette, IN 47907-1295

\section{OBJECTIVES}

The objective of the proposed research is to first characterize the enzymes involved in degrading organic sulfur in coal from some of the well-characterized organic sulfurdegrading strains. After the enzymes have been successfully purified, the genes encoding these enzymes will be cloned and the suitability of these microorganisms for recombinant manipulation will also be studied. Initially, the enzymes involved in the removal of organic sulfur from coal and from model compounds in two particular strains, IGTS8 and $\mathrm{K} 3 \mathrm{~B}$, will be characterized and analyzed. The scope of the proposed study covers the following:

1. Characterization, purification, and partial sequence analysis of the enzymes involved in the removal of organic sulfur from coal.

2. cloning of the genes encoding the organic sulfur-degrading $\mathrm{cnzz}^{\prime}$ 'mes from these two selected species in E. coli.

3. Sequence analysis of the cloned genes.

4. Attempting to clone and overexpress the organic sulfur degrading genes in their parent hosts as well as in other hosts.

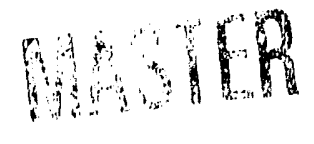




\section{DISCLAIMER}

This report was prepared as an account of work sponsored by an agency of the United States Government. Neither the United States Government nor any agency thereof, nor any of their employees, makes any warranty, express or implied, or assumes any legal liability or responsibility for the accuracy, completeness, or usefulness of any information, apparatus, product, or process disclosed, or represents that its use would not infringe privately owned rights. Reference herein to any specific commercial product, process, or service by trade name, trademark, manufarturer, or otherwise does not necessarily constitute or imply its endorsement, recommendation, or favoring by the United States Government or any agency thereof. The views and opinions of authors expressed herein do not necessarily state or reflect those of the United States Government or any agency thereof. 
IGTS8 is a derivative of Rhodococcus rhodochrous, which was introduced by Dr. J. J. Kilbane at the Institute of Gas Technology, Chicago, IL $(5,8,9)$, as being able to remove organic sulfur from coal and from model organic sulfur-containing compounds such as dibenzenethiophene (DBT)(Figure 3). IGTS8 appears to be able to oxidize organic sulfur in coal or model compounds to generate sulfate and to use the latter for its sulfur requirement for growth. Dr. Kilbane and co-workers have shown that IGTS8 degrades DB' $\mathrm{T}$ by the $4 \mathrm{~S}$ mechanism (5). Furthermore, IGTS8 can also degrade other organic sulfur bonds such as thiols, sulfides, and disulfides (Kilbane personal communication).

IGTS8 appears to be a stable strain for degrading organic sulfur, since it has been used for coal desulfurization studies for nearly two years without losing its ability in the removal of organic sulfur from coal.

We are interested in the determination of the factors, presumabiy that they are enzymes, involved in the removal of organic sulfur from model compounds and coal. Since coal has a gigantic macromolecular structure, we assume that the factors to be able to remove organic sulfur bonds in coal has to be -ither secreted from the cell or be absorbed on the cell surface. Our preliminary results indicated results indicate that these enzymes are associated with the cell surface. For example, the medium was found to contain very little activity, but the membrane fraction contained most of the activity. Furthermore, SDS-PAGE analysis indicated that IGTS8 secretes very few enzymes into the culture medium. This part of work was carried out prior to the initiation of this grant. 
Proteins are known to be associated with the cell surface by different mechanisms. They may be attached to the cell surface through ionic interactions, hydrophobic stems, or special anchoring structure. These various possibilities will be taken into consideration for designing protocols for the purification of these enzymes.

Since we have already established that the factors, presumably the enzymes, are associated with the cell surface, we studied whether these factors (enzymes) are associated with the cell surface only peripherally. For these studies, we treated the cells with salt at various strengths; EDTA, at various concentrations, and acids at various strength and pHs. We concluded that under the various conditions that we have used, the factors (enzymes) seem to not be peripherally attached to the cell surface. Next, we investigated whether the factors (enzymes) are firmly anchored in the cellular membrane. We have used various detergents trying to release the factors (enzymes) from the cell membrane. We found that the factors (enzymes) can be released from the cells by treatment with some of the detergents. Subsequently, we also investigated whether it is possible to release the factors (enzymes) by some of the proteases which are known to be able to release proteins which are attached to the membrane via a hydrophobic stem. Indeed, we also fourd that some of the protease could specifically release the factors (enzymes) from the cell surface and the released factors (enzymes) are till active in degrading DBT to a product which produces a positive test with the Gibbs reagent. These results seem to imply that the factors of IGTS8 for degrading organic sulfur are enzymes. 
After we have accomplished this much in the study of the factors (enzymes) from IGTS8 responsible for degrading DBT, we tried to repeat the same studies on the microorganism, K3B.

$\mathrm{K} 3 \mathrm{~B}$ is another microorganism that we chose to study. $\mathrm{K} 3 \mathrm{~B}$ was generously provided to us by Drs. G. J. Olson and M. D. Dahlberg of Pittsburgh Energy Technology Center. They have shown that K3B can effectively degrade DBT-sulfone to sulfate and benzoic acid derivatives and it can use DBT sulfone as its sole carbon and/or energy source for growth, but it cannot metabolize DBT.

We found that the organic-sulfur-degrading activity of $\mathrm{K} 3 \mathrm{~B}$ can also be released by the same detergents and proteases used to release the factors (enzymes) present in K3B.

In the coming quarter, attempts will be made to define the conditions that can effectively release organic-sulfur-degrading factors (enzymes) from IGTS8 and K3B. Attempts will also be made to further purify these factors (enzymes). 

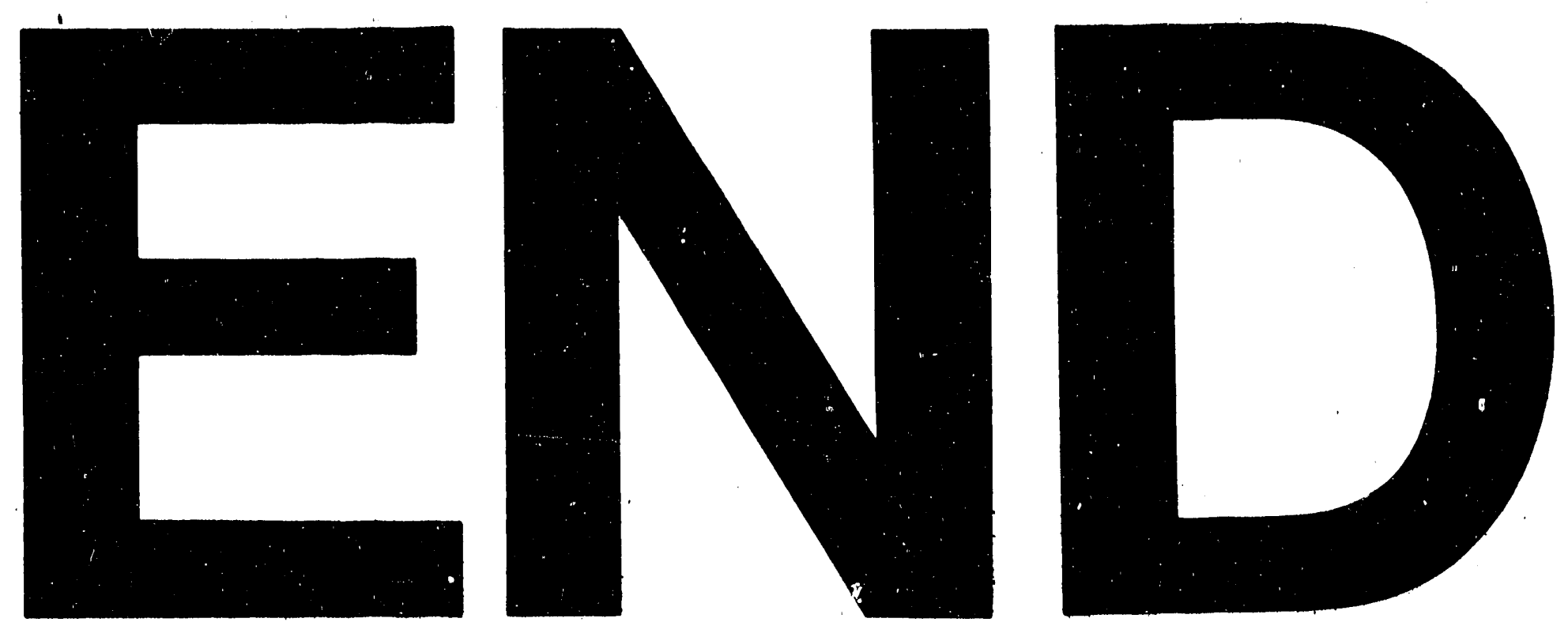

w

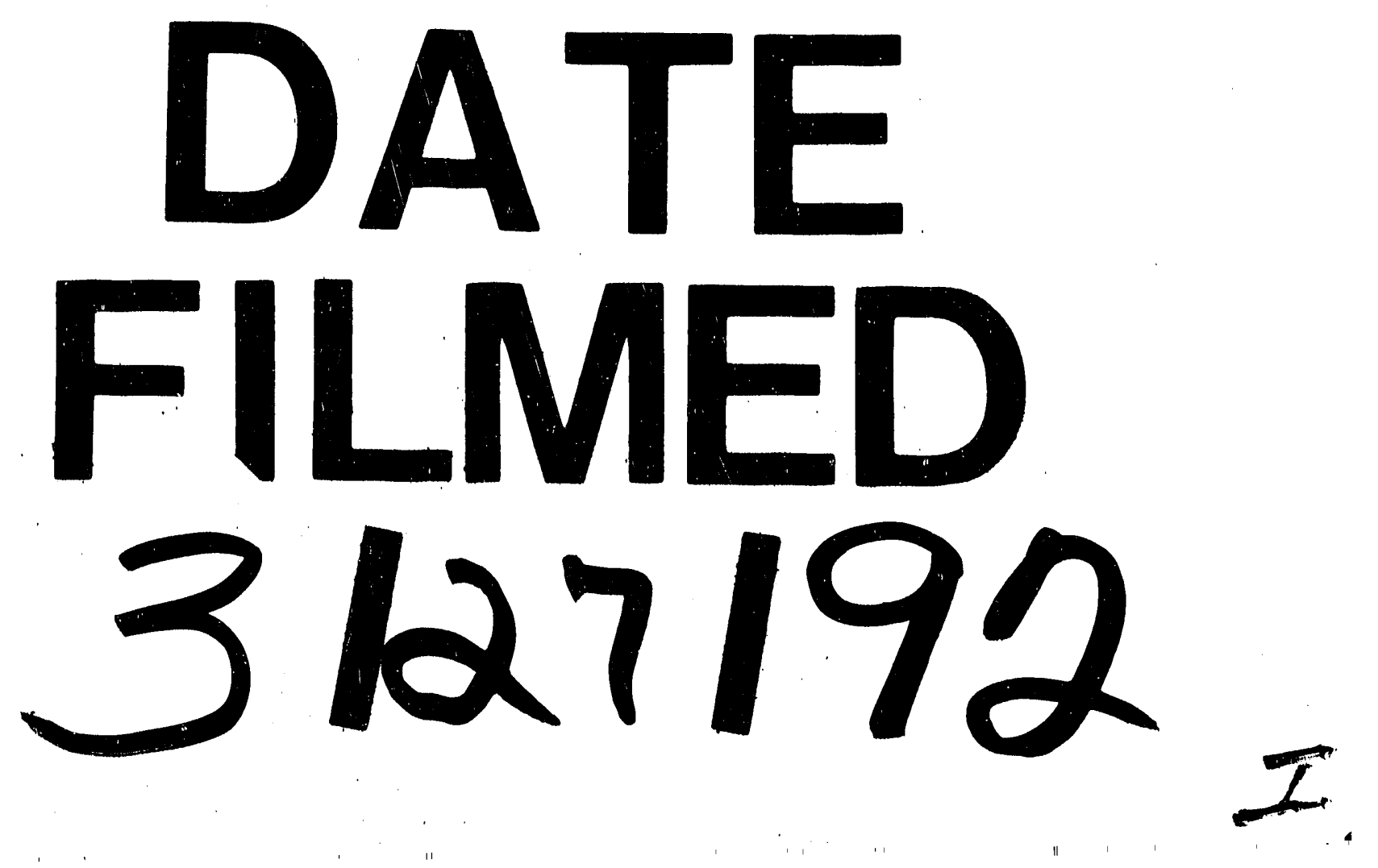




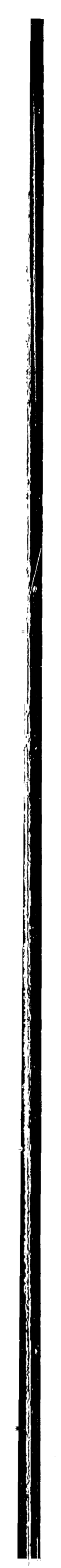

